\title{
Pengaruh Kualitas Institusi, Pengeluaran Pemerintah, dan Foreign Direct Investment terhadap Pertumbuhan Ekonomi
}

\author{
Anastia Widianatasari ${ }^{1)^{*}}, 2^{\text {nd }}$ Evi Yulia Purwanti ${ }^{2)}$ \\ 1)2) Ilmu Ekonomi, Universitas Diponegoro, Kota Semarang, Indonesia \\ *E-mail corresponding author: anastiawidianatasari@gmail.com
}

Received: 23-06-2021;

Accepted: 25-08-2021;

Available online: 31-10-2021

\section{Ecoplan}

Vol. 4 No. 2, Oktober 2021, hlm 86-98

\section{ISSN p: 2620-6102 e: $2615-5575$}

Abstract - Economic growth in developing countries is prone to global economic fluctuations such as the 2008 financial crisis. This study has two objectives. First, analyze institutional quality, government expenditure, and foreign direct investment on economic growth. Second, analyze institutional quality and government expenditure on economic development through FDI. This study uses two analytical methods: panel data regression and the common effect model (CEM) approach and path analysis. The objects used in the research were nine developing countries in Asia in 2012-2019. The finding revealed that three variables of institutional quality have a significant effect on economic growth. There is a negative effect of voice and accountability, a positive effect of political stability, the absence of violence/terrorism, and the regulatory quality. Meanwhile, control of corruption does not affect economic growth. In addition, government expenditure has no significant impact on economic growth, whereas foreign direct investment has a significant negative effect. Furthermore, all institutional quality variables have no significant effect on economic development through FDI, but government expenditure has a significant negative impact on economic growth via FDI. Governments can carry out regulatory reforms, review government spending allocations, and control FDI inflows to stimulate economic growth in developing countries.

\author{
Keywords: Institutional \\ Quality, Government \\ Expenditure, Foreign \\ Direct Investment, \\ Economic Growth
}

\begin{abstract}
Abstrak - Pertumbuhan ekonomi di negara berkembang rentan terhadap fluktuasi ekonomi global seperti krisis keuangan 2008. Penelitian ini memiliki dua tujuan. Pertama, menganalisis pengaruh kualitas institusi, pengeluaran pemerintah, dan foreign direct investment terhadap pertumbuhan ekonomi. Kedua, menganalisis pengaruh kualitas institusi dan pengeluaran pemerintah terhadap pertumbuhan ekonomi melalui FDI. Penelitian ini menggunakan dua metode analisis, yaitu regresi data panel pendekatan common effect model (CEM) dan analisis jalur. Objek yang digunakan penelitian 9 negara berkembang Asia tahun 2012-2019. Hasil penelitian menunjukkan bahwa tiga variabel kualitas institusi berpengaruh signifikan terhadap pertumbuhan ekonomi. Ada voice and accountability yang berpengaruh negative, dan political stability and absence of violence/ terrorism serta regulatory quality yang berpengaruh positif. Sementara itu, control of corruption tidak berpengaruh signifikan terhadap pertumbuhan ekonomi. Di samping itu, pengeluaran pemerintah tidak berpengaruh signifikan terhadap pertumbuhan ekonomi, tetapi foreign direct investment berpengaruh negatif signifikan terhadap pertumbuhan ekonomi. Lebih lanjut, secara tidak langsung semua variabel kualitas institusi tidak berpengaruh signifikan terhadap pertumbuhan ekonomi melalui FDI, tetapi pengeluaran pemerintah berpengaruh negatif signifikan terhadap pertumbuhan ekonomi melalui FDI. Pemerintah dapat melakukan reformasi regulasi, meninjau kembali alokasi pengeluaran pemerintah, dan menyaring arus masuk FDI untuk meningkatkan pertumbuhan ekonomi di negara berkembang.
\end{abstract}

Kata Kunci: Kualitas Institusi, Pengeluaran Pemerintah, Foreign Direct Investment, Pertumbuhan Ekonomi 
PENDAHULUAN

Pertumbuhan ekonomi yang inklusif merupakan salah satu tujuan pembangunan berkelanjutan yang menjadi orientasi pembangunan dunia saat ini. Pertumbuhan ekonomi didefinisikan sebagai proses jangka panjang di mana suatu negara mengalami peningkatan kapabilitas dalam memproduksi barang dan jasa untuk penduduknya (Jhingan, 2011). Banyak faktor yang mempengaruhi pertumbuhan ekonomi, seperti sumber daya alam, sumber daya manusia, maupun faktor non ekonomi, misalnya sistem kelembagaan masing-masing negara. Perbedaan kondisi tiap negara tersebut menyebabkan pendapatan atau pertumbuhan ekonomi antar negara berbeda.

Berdasarkan pendapatannya, negara-negara di dunia diklasifikasikan menjadi negara berpendapatan rendah, menengah, dan tinggi. Dari tiga kelompok negara tersebut, negara berpendapatan menengah atau yang bisa disebut negara emerging and developing economies ini telah memiliki performa yang semakin baik sejak tahun 2000 (Abiad et al., 2015). Dalam Laporan Perekonomian Indonesia 2020 disebutkan bahwa pertumbuhan ekonomi advance market tahun 2019 hanya 1,7\%, sementara pertumbuhan ekonomi emerging and developing economies justru lebih besar, yaitu 3,7\% (Badan Pusat Statistik, 2020).

Salah satu kawasan dengan banyak negara emerging and developing economies yang berpotensi menjadi penggerak utama perekonomian global adalah Asia (Priyajati dan Haryanto, 2020). Berdasarkan Laporan Perekonomian Indonesia 2020, rata-rata pertumbuhan ekonomi negara berkembang di Asia sebesar 5,5\% pada tahun 2019, lebih tinggi dari rata-rata pertumbuhan ekonomi negara maju sebesar $1,7 \%$ dan pertumbuhan ekonomi global sebesar 2,9\% (Badan Pusat Statistik, 2020). Beberapa negara yang tergolong negara emerging and developing economies menurut World Economic Outlook: A Long and Difficult Ascent adalah Bangladesh, Kamboja, China, India, Indonesia, Malaysia, Filipina, Sri Lanka, dan Vietnam (Asia-9) (International Monetary Fund, 2020).

Namun, Felipe, Abdon dan Kumar (2012) menyatakan negara berpendapatan menengah dapat berpotensi terjebak dalam middle income trap atau kondisi di mana negara telah mencapai pendapatan menengah, tetapi pertumbuhannya stagnan dan sulit untuk mencapai pendapatan tinggi. Kondisi tersebut terjadi ketika negara berpendapatan menengah tidak mampu mengembangkan keunggulan komparatifnya. Selain itu, pertumbuhan ekonomi di negara-negara tersebut juga rentan terhadap fluktuasi ekonomi global maupun internal (Oktaviani, Aimon dan Putri, 2019).

Salah satunya adalah krisis ekonomi global tahun 2008 yang berawal dari Amerika Serikat akibat subprime mortgage. Krisis ekonomi global 2008 disebabkan oleh beberapa hal, antara lain harga minyak dunia tinggi sehingga mendorong harga bahan pangan, inflasi global, krisis perkreditan yang menyebabkan lembaga bank komersial dan bank investasi besar bangkrut, serta tingginya pengangguran (Hidayat, 2008). Interdependensi ekonomi antar negara turut menyebabkan kawasan Asia memperoleh dampak krisis ekonomi 2008 karena harus mempertaruhkan cadangan devisa negara. Hal ini mengakibatkan pertumbuhan ekonomi di Asia, khususnya negara berkembang yang rentan terhadap fluktuasi ekonomi terus menurun. Dapat dilihat perolehan produk domestik bruto per kapita di Asia-9 tahun 2015-2019 di bawah ini.

Tabel 1. Produk Domestik Bruto per Kapita Asia-9 tahun 2015-2019

\begin{tabular}{lrrrrr}
\hline NEGARA & $\mathbf{2 0 1 5}$ & $\mathbf{2 0 1 6}$ & $\mathbf{2 0 1 7}$ & $\mathbf{2 0 1 8}$ & $\mathbf{2 0 1 9}$ \\
\hline Bangladesh & 1.002 & 1.062 & 1.127 & 1.203 & 1.288 \\
Kamboja & 1.025 & 1.080 & 1.136 & 1.203 & 1.269 \\
China & 6.500 & 6.908 & 7.347 & 7.807 & 8.242 \\
India & 1.752 & 1.876 & 1.987 & 2.086 & 2.152 \\
Indonesia & 3.824 & 3.968 & 4.121 & 4.285 & 4.451 \\
Malaysia & 10.912 & 11.244 & 11.737 & 12.131 & 12.487 \\
Filipina & 2.735 & 2.887 & 3.043 & 3.191 & 3.338 \\
Sri Lanka & 3.647 & 3.769 & 3.860 & 3.946 & 4.012 \\
Vietnam & 1.667 & 1.753 & 1.853 & 1.964 & 2.082 \\
\hline
\end{tabular}

Sumber: World Development Indicators, 2021

Tabel 1 menunjukkan kesembilan negara tersebut memperolah nilai produk domestik bruto yang semakin meningkat tiap tahunnya. Akan tetapi, jumlah peningkatan produk domestik bruto menurun tiap 
tahunnya. Pada tahun 2015 rata-rata pertumbuhan produk domestik bruto sebesar 5,06\%, kemudian terus menurun pada tahun selanjutnya sebesar 5,05\%, 5,04\%, 4,93\% hingga pada tahun 2019 mencapai 4,48\%. Oleh sebab itu, dalam rangka memperbaiki kondisi perekonomian di Asia-9 diperlukan upaya untuk mendorong peningkatan pertumbuhan ekonomi dengan meningkatkan faktor-faktor yang dapat mempengaruhi peningkatan produk domestik bruto.

Investasi adalah salah satu faktor utama yang mempengaruhi pertumbuhan ekonomi suatu negara karena semakin besar porsi PDB yang ditabung dan diinvestasikan, semakin besar pula pertumbuhan ekonominya. Jadi, agar suatu negara mengalami pertumbuhan ekonomi harus menabung dan menginvestasikan bagian tertentu dari PDB. Perekonomian yang sudah mengglobal dan saling terintegrasi membuat investor yang memiliki lebih banyak modal memperluas pada dengan menginvestasikannya ke negara lain sehingga investasi tidak hanya berasal dari dalam negeri, tetapi juga luar negeri. Salah satu bentuk investasi yang berasal dari negara lain adalah Foreign Direct Investment (FDI), yaitu penanaman modal yang dilakukan oleh perusahaan multinasional dari suatu negara ke negara lain (Todaro dan Smith, 2010). FDI merupakan salah satu bagian dari proses globalisasi ekonomi yang berkaitan dengan kerja sama ekonomi antar negara karena arus investasi mengalir dari suatu negara ke negara lain.

Setiap negara berusaha meningkatkan daya saing dan daya tarik investasi untuk menarik para investor dari perusahaan multinasional agar berinvestasi di negaranya karena FDI dapat berkontribusi terhadap pembangunan suatu negara dengan adanya transfer aset, keahlian manajemen, dan teknologi (Anwar et al., 2016). FDI juga dapat meningkatkan taraf hidup masyarakat dengan adanya peningkatan kesempatan kerja yang bermanfaat untuk meningkatkan kesejahteraan masyarakat (Febriana dan Muqorobbin, 2014). Di samping itu, menurut Zahran (2020) keuntungan FDI bagi investor dari negara asal adalah dana yang diinvestasikan lebih produktif sehingga lebih banyak keuntungan yang diperoleh.

Berkembangnya FDI menjadi salah satu modal pembangunan nasional menjadikan persaingan antar negara dalam menarik FDI semakin kompetitif. Alfaro, Kalemli-Ozcan dan Volosovych (2005) menyatakan bahwa kondisi negara yang stabil dan iklim investasi yang kondusif menjadi salah satu faktor yang menarik arus masuk FDI. Kondisi tersebut tercipta dari sistem dan kebijakan masing-masing negara. Hal ini berarti bahwa FDI tidak terlepas dari kualitas pelayanan pemerintah di suatu negara terhadap stakeholders, dalam hal ini terhadap investor asing, Apabila pelayanan berkualitas maka investor tertarik untuk berinvestasi di negara tersebut, begitu juga sebaliknya. Oleh karena itu, upaya peningkatan daya saing dan saya tarik investasi suatu negara melalui berbagai kebijakan ekonomi termasuk melalui perbaikan kualitas institusi sangat penting.

Menurut Daniele dan Marani (2006), kualitas institusi yang baik akan menarik FDI melalui 3 jalur utama. Pertama, kualitas institusi yang baik sapat menarik investasi karena dapat meningkatkan produktivitas. Kedua, kualitas institusi yang baik dapat mengurangi biaya transaksi dalam proses investasi dan bisnis. Ketiga, dengan kualitas institusi yang baik keamanan hak milik perusahaan multinasional yang berinvestasi di suatu negara lebih terjamin. Dengan demikian, institusi dengan regulasi yang jelas, kondisi politik yang stabil, birokrasi yang tidak rumit, dan tingkat korupsi yang rendah berpotensi mendorong aliran investasi ke suatu negara di mana investasi tersebut berguna sebagai modal pembangunan untuk mencapai target pertumbuhan ekonomi.

Sementara itu, berdasarkan teori ekonomi kelembagaan baru atau new institutioanl economics (NIE), institusi berpengaruh terhadap kinerja perekonomian. Institusi yang baik dengan menekan biaya melalui pengurangan ketidakpastian dan perwujudan struktur yang stabil dalam melalui pertukaran, perjanjian jual beli, atau bentuk interaksi lainnya (North, 1990). Sejalan dengan pendapat Acemoglu, Johnson dan Robinson (2005) yang menyatakan bahwa kualitas institusi dapat mempengaruhi pertumbuhan ekonomi karena institusi bagaimana kebijakan alokasi sumber daya di suatu negara menentukan.

Asghar, Qureshi dan Nadeem (2015) berpendapat bahwa peningkatan pertumbuhan ekonomi di negara berkembang Asia membutuhkan perbaikan kualitas institusi. Perbaikan kualitas institusi dapat mendukung tercapainya target pembangunan karena kualitas institusi mengindikasikan bagaimana pengaturan kebijakan dalam pembangunan suatu negara (Ramadhan, 2019). Selain itu, kualitas institusi atau tata kelola pemerintahan berperan penting untuk meningkatkan daya saing bangsa dan memperbaiki kualitas hidup masyarakat (Huang dan Ho, 2016)

Selain melalui perbaikan kualitas institusi, untuk mendorong pertumbuhan ekonomi pemerintah perlu melakukan intervensi dalam pembangunan melalui berbagai kebijakan ekonomi. Salah satunya melalui kebijakan anggaran pengeluaran pemerintah. Pengeluaran pemerintah merupakan salah satu bentuk kontribusi pemerintah dalam pembangunan melalui kebijakan fiskal yang dapat merangsang pertumbuhan ekonomi melalui masuknya FDI ke suatu negara. Sebab, pengeluaran pemerintah yang digunakan untuk membangun infrastruktur, peningkatan kualitas pelayanan publik, perwujudan fasilitas dan lingkungan 
bisnis yang memadai, dan kebijakan lain dapat menarik arus masuk FDI sebagai modal pembangunan (Yuan, Chen dan Wang, 2010).

Pengeluaran pemerintah merupakan salah satu intervensi pemerintah untuk mengatasi kegagalan pasar dan mempercepat pertumbuhan ekonomi. Menurut Mankiw (2018), pengeluaran pemerintah berguna untuk membiayai pembangunan nasional, seperti pembangunan infrastruktur, investasi modal manusia, dan perlindungan sosial. Namun, tidak setiap pengeluaran pemerintah yang tinggi berdampak positif terhadap pertumbuhan ekonomi. Berdasarkan teori pertumbuhan ekonomi neoklasik, kebijakan fiskal ekspansif dapat menyebabkan kerugian perekonomian. Hal itu dikarenakan pengeluaran pemerintah yang terlalu tinggi dapat menimbulkan defisit yang lebih tinggi dan menyebabkan crowding out investasi. Terjadinya crowding out investasi ini disebabkan oleh adanya kebijakan fiskal yang akan mengakibatkan inflasi yang pada akhirnya akan menimbulkan kenaikan suku bunga. Kenaikan suku bunga tersebut menyebabkan investasi terhambat dan akan berdampak pula bagi pertumbuhan ekonomi (Farasianita, 2019).

Dari uraian di atas dapat disimpulkan bahwa penting untuk mengetahui faktor apa saja yang mempengaruhi pertumbuhan ekonomi di Asia-9 sebagai negara berkembang yang rentan terhadap fluktuasi ekonomi global dan middle income trap. Terlebih setelah krisis ekonomi 2008 pertumbuhan ekonomi Asia9 cenderung menurun. Untuk itu diperkirakan FDI sebagai modal pembangunan, sistem kelembagaan yang tercermin dari kualitas institusi, dan intervensi pemerintah melalui kebijakan ekonomi yang tercermin oleh besarnya pengeluaran pemerintah dapat mempengaruhi pertumbuhan ekonomi. Di sisi lain, sebagai pembaruan penelitian FDI juga akan ditempatkan sebagai variabel mediasi pada pengaruh kualitas institusi dan pengeluaran pemerintah terhadap pertumbuhan ekonomi. Oleh karena itu, penelitian ini bertujuan untuk: 1) menganalisis pengaruh kualitas institusi, pengeluaran pemerintah, dan foreign direct investment terhadap pertumbuhan ekonomi di Asia-9 tahun 2012-2019; 2) menganalisis pengaruh kualitas institusi dan pengeluaran pemerintah terhadap pertumbuhan ekonomi melalui FDI di Asia-9 tahun 2012-2019.

\section{TINJAUAN PUSTAKA}

Pertumbuhan Ekonomi

Menurut Kuznets, pertumbuhan ekonomi merupakan proses jangka panjang di mana suatu negara mengalami peningkatan kapabilitas dalam memproduksi barang dan jasa yang disuplai untuk penduduknya (Jhingan, 2011). Pertumbuhan ekonomi dapat dipengaruhi oleh berbagai faktor ekonomi, seperti sumber daya alam, sumber daya manusia, akumulasi modal, dan teknologi maupun faktor ekonomi, misalnya sistem kelembagaan, kondisi politik, dan sistem sosial. Selain itu, Case, Fair dan Oster (2012) menyebutkan bahwa pertumbuhan ekonomi merupakan hasil dari kebijakan ekonomi di suatu negara. Pertumbuhan ekonomi dapat diukur dengan peningkatan produk domestik bruto, yaitu nilai pasar barang dan jasa akhir yang dapat diproduksi oleh seluruh unit ekonomi di suatu negara pada periode tertentu dengan faktor-faktor produksi yang ada (Mankiw, 2018).

\section{Teori Pertumbuhan Ekonomi Neoklasik}

Mankiw (2010) menyebutkan bahwa model pertumbuhan ekonomi Solow menjelaskan interaksi perubahan modal, perubahan tenaga kerja, dan perubahan teknologi eksogen dalam perekonomian dan pengaruhnya terhadap pertumbuhan output barang dan jasa dalam sebuah perekonomian. Dalam model ini, teknologi dianggap sebagai sesuatu yang eksogen dan berinteraksi dengan variabel lain dalam proses pertumbuhan ekonomi. Asumsi utama yang digunakan dalam model Solow yaitu modal akan mengalami diminishing returns sehingga dalam jangka panjang tingkat persediaan modal akan sama dengan depresiasinya. Pada kondisi tersebut pertumbuhan output per tenaga kerja dan modal per tenaga kerja 0 atau perekonomian berada dalam kondisi mapan. Dengan demikian, dalam jangka panjang perekonomian mengalami konvergensi pendapatan.

\section{Teori Pertumbuhan Ekonomi Endogen}

Teori pertumbuhan ekonomi endogen menjelaskan faktor-faktor pertumbuhan ekonomi yang ditentukan secara endogen di mana faktor-faktor endogen belum dijelaskan dalam teori ekonomi neoklasik Solow atau bisa disebut "Solow Residual". Tidak seperi teori neoklasik yang menganggap adanya diminishing marginal returns, teori ini justru menganggap investasi akan menghasilkan tingkat output yang lebih tinggi atau increasing return to scale (Todaro dan Smith, 2012). Oleh sebab itu, teori ini menganggap adanya divergensi pendapatan antar negara. Pertumbuhan ekonomi endogen juga mendukung peran kebijakan publik. Hal itu untuk merangsang pembangunan ekonomi baik melalui investasi langsung maupun tidak langsung, baik investasi dalam bentuk modal, manusia, maupun ilmu pengetahuan atau teknologi. Pemerintah dapat menyediakan barang publik seperti infrastruktur dan menyediakan lingkungan 
kelembagaan yang baik atau kebijakan lain untuk memacu investasi yang dalam meningkatkan akumulasi modal (Jhingan, 2011).

\section{Teori New Institutional Economics}

Menurut Acemoglu, Johnson dan Robinson (2005) institusi ekonomi menjadi hal utama yang menyebabkan perbedaan kemakmuran antar negara. Hal utama dalam perekonomian adalah institusi ekonomi yang ada di masyarakat seperti struktur hak milik dan kesempurnaan pasar. Institusi dapat menciptakan struktur yang stabil dalam interaksi manusia dalam hal politik, ekonomi, maupun sosial untuk menekan biaya transaksi dan mengurangi ketidakpastian dalam aktivitas ekonomi. Jadi, institusi penting untuk menciptakan struktur insentif dalam aktivitas ekonomi. Pelaku ekonomi tidak akan mendapat insentif dalam melakukan investasi, baik modal fisik, manusia, dan teknologi tanpa adanya hak kepemilikan. Institusi juga berperan untuk mengalokasikan sumber daya supaya lebih efisien ketika pasar berada dalam kondisi tidak sempurna atau alokasi sumber daya tidak efisien. Maka dari itu, diperlukan institusi yang mendorong akumulasi modal, inovasi, dan efisiensi alokasi untuk meningkatkan kesejahteraan rakyat dan mencapai target pertumbuhan ekonomi.

\section{Foreign Direct Investment}

Menurut Todar dan Smith (2012), FDI merupakan proses penanaman modal dari suatu negara (host country) ke negara lain (home country) yang dilakukan oleh perusahaan swasta multinasional. Foreign direct investment dapat menjadi modal pembangunan untuk mencapai target pertumbuhan ekonomi negara tujuan melalui kontribusi FDI dalam mengisi kesenjangan antara kebutuhan modal dan modal aktual yang ada untuk mencapai target pertumbuhan ekonomi, kesenjangan devisa, maupun kesenjangan pendapatan negara. Selain itu, adanya aliran masuk FDI juga memungkinkan adanya transfer pengetahuan dan keterampilan bagi mitra lokal melalui learning by doing dan pelatihan maupun kemajuan teknologi. Hal tersebut dapat meningkatkan produktivitas negara tujuan investasi.

\section{Kualitas Institusi}

Institusi merupakan aturan yang ada di suatu masyarakat (North, 1990). Menurut KBBI, kualitas artinya baik atau buruknya sesuatu sehingga kualitas institusi merupakan baik atau buruknya aturan yang mengatur interaksi di suatu masyarakat. Dalam sistem ketatanegaraan, institusi artinya suatu aturan yang dibuat oleh pemerintah untuk mengatur interaksi sosial, ekonomi, dan politik masyarakat di suatu negara. Kaufmann, Kraay dan Mastruzzi (2011) mendefinisikan kualitas institusi sebagai proses bagaimana pemilihan, pemantauan, dan pergantian pemerintah termasuk efektivitas pemerintah dalam merumuskan dan menerapkan kebijakan, serta kepedulian masyarakat dalam mengimplementasikan norma yang mengatur kegiatan sosial dan ekonomi suatu negara.

Dalam Worldwide Governance Indicators, kualitas institusi mempunyai 6 indikator yang dinilai dengan skala antara -2,5 hingga +2,5 (Kaufmann, Kraay dan Mastruzzi, 2011). Penelitian ini menggunakan 4 dari 6 indikator kualitas institusi dengan tujuan menghindari adanya gejala multikoleniaritas pada indikator government effectiveness dan rule of law. Dengan demikian, penelitian ini menggunakan indikator kualitas institusi sebagai berikut:

1) Voice and accountability: Tingkat partisipasi masyarakat dalam penyelenggaraan pemerintah, termasuk kebebasan berpendapat, berserikat, dan kebebasan media.

2) Political stability and absence of violence/ terrorism: Tingkat stabilitas kondisi pemerintahan dan tidak adanya kemungkinan penggulingan secara tidak konstitusional maupun kekerasan bermotif politik termasuk terorisme.

3) Regulatory quality: Tingkat kemampuan pemerintah dalam merumuskan dan menerapkan kebijakan untuk mendorong pengembangan sektor swasta.

4) Control of corruption: Tingkat penguasaan kepentingan publik untuk keuntungan pribadi, baik dalam julah besar maupun kecil, serta tingkat penguasaan negara oleh kelompok elite.

Pengeluaran pemerintah

Pengeluaran pemerintah merupakan gambaran kebijakan fiskal yang diterapkan pemerintah suatu negara. Pengeluaran pemerintah merupakan ukuran kontribusi pemerintah dalam pembangunan suatu negara dalam hal pembelian barang dan jasa publik dan perlindungan sosial bagi masyarakat. Mankiw (2018) menyatakan bahwa dalam kebijakan pengeluaran pemerintah para pembuat kebijakan akan menitikberatkan alokasi pengeluaran untuk tiga jenis. Pertama, pembangunan fasilitas umum, seperti pembangunan dan perbaikan jalan atau jembatan atau pembangunan infrastruktur lainnya. Kedua, bantuan anggaran untuk daerah. 
Ketiga, keperluan perlindungan sosial bagi masyarakat. Efektivitas pengeluaran pemerintah terhadap kinerja perekonomian tergantung produktif atau tidak penggunaannya (Othman et al., 2018).

\section{METODE PENELITIAN}

Jenis data yang digunakan untuk penelitian ini adalah data kuantitatif berbentuk data panel. Unit cross section yang diukur adalah 9 negara berkembang Asia yang diukur pada waktu penelitian dari tahun 2012 sampai 2019. Data yang akan diolah dalam penelitian ini dikumpulkan dari data yang dirilis oleh instansi terkait, yaitu World Bank dan Internasional Monetary Fund. Data yang dikumpulkan dari World Bank meliputi GDP per kapita dan arus masuk bersih FDI sebagai bagian dari PDB dalam World Development Indicators serta indeks kualitas institusi dari Worldwide Governance Indicators. Ideks kualitas institusi terdiri dari 4 indikator, yaitu voice and accountability, political stability and absence of violence/ terrorism, regulatory quality dan control of corruption. Data yang dikumpulkan dari IMF adalah persentase total pengeluaran pemerintah dari PDB dalam World Economic Outlook Database.

Teknik analisis yang digunakan adalah regresi data panel dengan pendekatan common effect model (CEM) dan analisis jalur dengan bantuan software SPSS v.23. Langkah-langkah analisis data pada penelitian ini terdiri atas: 1) uji asumsi klasik yang meliputi uji autokorelasi, heteroskedastisitas, multikoleniaritas, dan normalitas; 2) uji statistik F; 3) uji koefisien determinasi; 4) uji statistik t untuk menguji signifikansi pengaruh langsung; 5) uji Sobel untuk menguji signifikansi pengaruh tidak langsung; dan 6) uji koefisien jalur pengaruh langsung dan tidak langsung menggunakan standardized coefficient.

\section{Spesifikasi Model Penelitian}

Model persamaan yang digunakan dalam penelitian ini adalah persamaan struktural yang terdiri dari dua persamaan sub struktur untuk menunjukkan hubungan hipotesis. Persamaan pertama menunjukkan hubungan fungsional kualitas institusi dan pengeluaran pemerintah dengan FDI. Persamaan kedua menggambarkan hubungan fungsional kualitas institusi, pengeluaran pemerintah, dan FDI dengan pertumbuhan ekonomi. Karena struktur data yang digunakan adalah data panel maka setiap persamaan sub struktur menggunakan model persamaan common effect model, yaitu dengan menambahkan subjek $(i)$ dan periode $(t)$ tiap variabel. Dengan demikian, persamaan yang dapat disusun adalah:

$$
\begin{aligned}
& F D I_{i t}=b_{1} V A_{i t}+b_{2} P S_{i t}+b_{3} R Q_{i t}+b_{4} C C_{i t}+b_{5} G S_{i t} \ldots \ldots \ldots \ldots \ldots \ldots \ldots \ldots \ldots \\
& G D P_{i t}=b_{6} V A_{i t}+b_{7} P S_{i t}+b_{8} R Q_{i t}+b_{9} C C_{i t}+b_{10} G S_{i t}+b_{11} F D I_{i t}
\end{aligned}
$$

Keterangan:

$\begin{array}{ll}G D P & : \text { Produk domestik bruto } \\ F D I & : \text { Foreign direct investment } \\ V A & : \text { Voice and accountability } \\ P S & : \text { Political stability and absence of violence/ terrorism } \\ R Q & : \text { Regulatory quality } \\ C C & : \text { Control of Corruption } \\ G S & : \text { Government Expenditure } \\ b_{1}-b_{11}: \text { Koefisien jalur/ koefisien regresi terstandarisasi } \\ i & : \text { Unit cross section } \\ t & : \text { Tahun ke } 1,2,3, \ldots . ., 8\end{array}$

Berkaitan dengan konsistensi, variabel-variabel dalam model akan ditransformasikan dengan logaritma natural. Karena data variabel-variabel kualitas institusi merupakan data interval $-2,5$ hingga $+2,5$ maka nilai tersebut ditambah dengan konstanta 3 terlebih dahulu untuk menghindari angka 0 dan negatif. Masron dan Abdullah (2010) telah melakukan cara ini sebelumnya. Penambahan konstanta tersebut tidak mengubah interpretasi dari masing-masing variabel, yaitu semakin tinggi nilai suatu indikator semakin baik pula indikator kualitas institusi tersebut. Selanjutnya, dilakukan transformasi pada variabel yang belum memiliki satuan persen, yaitu variabel kualitas institusi dan pertumbuhan ekonomi. Jadi, model penelitian yang diuji adalah:

$F D I_{i t}=b_{1} L n V A_{i t}+b_{2} L n P S_{i t}+b_{3} L n R Q_{i t}+b_{4} L b C C_{i t}+b_{5} G S_{i t}$

$L n G D P_{i t}=b_{6} \operatorname{LnV} A_{i t}+b_{7} L n P S_{i t}+b_{8} L n R Q_{i t}+b_{9} L n C C_{i t}+b_{10} G S_{i t}+b_{11} F D I_{i t} \ldots$ (4) 
HASIL DAN PEMBAHASAN

Uji Asumsi Klasik

Uji Autokorelasi

Tabel 2. Uji Autokorelasi Persamaan 1 dan 2

\begin{tabular}{llllll}
\hline Model & Durbin-Watson & dL & dU & 4-dU & 4-dL \\
\hline 1 & 1,138 & 1,4732 & 1,7688 & 2,2312 & 2,5268 \\
2 & 0,938 & 1,4623 & 1,8011 & 2,1989 & 2,5377 \\
\hline
\end{tabular}

Berdasarkan tabel 2, dapat disimpulkan bahwa kedua persamaan memiliki gejala autokorelasi positif karena nilai durbin-watson yang kurang dari nilai dL. Oleh karena itu, dilakukan penyembuhan dengan metode Cochrane Orcutt dengan basis lag 1 sehingga model penelitian ditransformasikan menjadi:

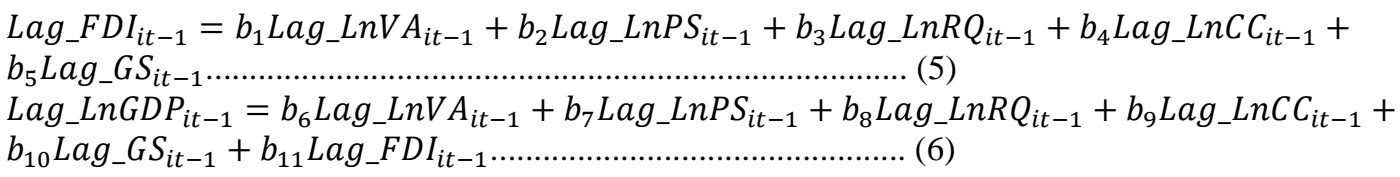

Tabel 3. Uji Autokorelasi Persamaan 1 dan 2 Setelah Penyembuhan

\begin{tabular}{llllll}
\hline Model & Durbin Watson & dL & dU & 4-dU & 4-dL \\
\hline 1 & 1,942 & 1,4685 & 1,7685 & 2,2318 & 2,5315 \\
2 & 1,806 & 1,4379 & 1,8021 & 2,1979 & 2,5621 \\
\hline
\end{tabular}

Dari tabel 3 di atas dapat terlihat bahwa nilai durbin-watson untuk persamaan 1 dan 2 lebih besar dari nilai dU dan lebih kecil dari nilai 4-dU sehingga dapat dikatakan kedua persamaan tersebut terbebas dari gejala autokorelasi.

\section{Uji Heteroskedastisitas}

Tabel 4. Uji Heteroskedastisitas Persamaan 1 dan 2

\begin{tabular}{llll}
\hline Persamaan Sub-struktur 1 & \multicolumn{3}{c}{ Persamaan Sub-struktur 2 } \\
\hline Variabel & Sig. T & Variabel & Sig. t \\
\hline Voice and Accountability & 0,282 & Voce and Accountability & 0,123 \\
Political Stability & 0,972 & Political Stability & 0,158 \\
Regulatory Quality & 0,687 & Regulatory Quality & 0,227 \\
Control of Corruption & 0,367 & Control of Corruption & 0,276 \\
Pengeluaran pemerintah & 0,935 & Pengeluaran pemerintah & 0,330 \\
& & Foreign Direct Investment & 0,935 \\
\hline
\end{tabular}

Tabel 4 menunjukkan bahwa nilai signifikansi t untuk semua variabel pada persamaan 1 maupun 2 lebih dari 0,05. Artinya, variabel-variabel independen pada kedua model tidak berpengaruh signifikan terhadap absolut residual masing-masing model. Dengan demikian, persamaan 1 dan 2 tidak memiliki gejala heteroskedastisitas.

Uji Multikoleniaritas

Tabel 5. Uji Multikoleniaritas Persamaan 1 dan 2

\begin{tabular}{llll}
\hline Persamaan Sub-struktur 1 & \multicolumn{3}{l}{ Persamaan Sub-struktur 2 } \\
\hline Variabel & VIF & Variabel & VIF \\
\hline Voice and Accountability & 2,057 & Voice and Accountability & 1,938 \\
Political Stability & 1,791 & Political Stability & 1,955 \\
Regulatory Quality & 2,854 & Regulatory Quality & 3,218 \\
Control of Corruption & 2,117 & Control of Corruption & 4,602 \\
Pengeluaran pemerintah & 1,654 & Pengeluaran pemerintah & 1,785 \\
& & Foreign Direct Investment & 2,904 \\
\hline
\end{tabular}


Berdasarkan tabel 5, nilai VIF untuk semua variabel independen pada persamaan 1 dan 2 kurang dari. Hal itu berarti bahwa variabel-variabel independen pada masing-masing model tidak saling berkorelasi sehingga kedua model tersebut tidak mempunyai gejala multikoleniaritas.

Uji Normalitas

Tabel 6. Uji Normalitas Persamaan 1 dan 2

\begin{tabular}{lll}
\hline Persamaan & Test Statistic & Asymp. Sig. (2-tailed) \\
\hline 1 & 0,052 & 0,200 \\
2 & 0,070 & 0,200 \\
\hline
\end{tabular}

Tabel di atas menunjukkan nilai Asymp. Sig (2-tailed) untuk persamaan 1 dan 2 senilai 0,200 yang mana lebih besar dari 0,05. Berdasarkan hasil tersebut, dapat dimaknai bahwa residual data persamaan 1 dan 2 berdistribusi normal atau model 1 dan 2 memenuhi asumsi normalitas.

\section{Uji Statistik F}

Tabel 7. Uji Statistik F Persamaan 1 dan 2

\begin{tabular}{llll}
\hline Persamaan & F statistik & F Tabel & Sig. F \\
\hline 1 & 30,441 & 2,2440 & 0,000 \\
2 & 64,693 & 2,3560 & 0,000 \\
\hline
\end{tabular}

Nilai F statistik persamaan 1 sebesar 30,441 lebih besar dari nilai $\mathrm{F}$ tabel dengan kriteria $\alpha=0,05$; $\mathrm{df}_{1}(\mathrm{k}-1)=5$; dan $\mathrm{df}_{2}(\mathrm{n}-\mathrm{k}-1)=65$ sebesar 2,2440. Nilai signifikansi $\mathrm{F}$ statistik sebesar 0,000 yang mana lebih kecil dari 0,05 mendukung hasil tersebut. Artinya, secara simultan voice and accountability, political stability and absence of violencel terrorism, regulatory quality, control of corruption, dan pengeluaran pemerintah berpengaruh signifikan terhadap FDI.

Untuk nilai $F$ statistik persamaan 2 didapatkan hasil 64,693 yang mana lebih besar nilai $F$ tabel dengan kriteria $\alpha=0,05 ; \mathrm{df}_{1}(\mathrm{k}-1)=6$; dan $\mathrm{df}_{2}(\mathrm{n}-\mathrm{k}-1)=64$ sebesar 2,3560. Didukung pula dengan nilai signifikansi F statistik persamaan 2 yang lebih kecil dari 0,05 yaitu sebesar 0,000. Dengan demikian, secara simultan voice and accountability, political stability and absence of violencel terrorism, regulatory quality, control of corruption, pengeluaran pemerintah, dan FDI berpengaruh signifikan terhadap pertumbuhan ekonomi.

Uji Koefisien Determinasi

Tabel 8. Uji Koefisien Determinasi Persamaan 1 dan 2

\begin{tabular}{lllll}
\hline Persamaan & R & R Square & Adjusted R Square & Std. Error of the Estimates \\
\hline 1 & 0,837 & 0,701 & 0,678 & 1,42425 \\
2 & 0,927 & 0,858 & 0,845 & 0,17670 \\
\hline
\end{tabular}

Nilai $\mathrm{R}^{2}$ persamaan 1 sebesar 0,701. Artinya, kemampuan variabel-variabel independen yaitu voice and accountability, political stability and absence of violencel terrorism, regulatory quality, control of corruption, dan pengeluaran pemerintah dalam menjelaskan variasi variabel dependen yaitu FDI sebesar 0,71 atau $70,1 \%$. Sedangkan, sisanya yaitu $29,9 \%$ dijelaskan oleh variabel lain di luar model. Sementara itu, besarnya nilai eror untuk model persamaan 1 adalah 0,547 .

Selanjutnya, nilai $\mathrm{R}^{2}$ yang diperoleh persamaan 2 adalah 0,858 . Jadi, variabel-variabel independen yaitu voice and accountability, political stability and absence of violencel terrorism, regulatory quality, control of corruption, pengeluaran pemerintah dan FDI mampu menjelaskan variasi variabel dependen yaitu pertumbuhan ekonomi sebesar 0,858 atau $85,8 \%$. Sisanya yaitu sebesar $14,2 \%$ dijelaskan oleh variabel lain di luar model. Untuk nilai eror yang diperoleh persamaan 2 adalah 0,377.

Pengujian Pengaruh Langsung

Tujuan pertama pada penelitian ini yaitu menguji pengaruh kualitas institusi, pengeluaran pemerintah, dan foreign direct investment terhadap pertumbuhan ekonomi secara langsung. Hasil pengujian signifikansi individual untuk melihat signifikansi pengaruh langsung disajikan pada tabel 2. 
Tabel 2. Hasil Uji Statistik t Pengaruh Langsung

\begin{tabular}{llllll}
\hline Variabel & t statistik & $\mathbf{t}$ tabel & Sig. $\mathbf{t}$ & Koefisien & Ket (2-tailed) \\
\hline VA & $-4,830$ & $-1,998$ & 0,000 & $-0,316$ & Signifikan \\
PS & 2,268 & 1,998 & 0,027 & 0,149 & Signifikan \\
RQ & 9,264 & 1,998 & 0,000 & 0,781 & Signifikan \\
CC & $-0,786$ & $-1,998$ & 0,434 & $-0,079$ & Tidak Signifikan \\
GS & 0,288 & 1,998 & 0,774 & 0,018 & Tidak Signifikan \\
FDI & $-7,303$ & $-1,998$ & 0,000 & $-0,585$ & Signifikan \\
\hline
\end{tabular}

Nilai t statistik voice and accountability adalah $-4,830$ yang mana lebih kecil dari nilai -t tabel dengan kriteria $\alpha=0,05$ dan df $(n-k)=71-7=64$ sebesar $-1,998$. Artinya, secara parsial variabel voice and accountability berpengaruh signifikan terhadap pertumbuhan ekonomi. Tanda negatif pada koefisien menunjukkan arah pengaruh voice and accountability terhadap pertumbuhan ekonomi negatif atau berlawanan arah. Artinya, jika voice and accountability meningkat sebesar 1 standar deviasi maka pertumbuhan ekonomi akan menurun sebesar 0,316 standar deviasi, berlaku juga sebaliknya. Hasil ini sejalan dengan penelitian Radulovic (2020).

Ketika partisipasi masyarakat dalam menyuarakan pendapat tinggi akan ada kelompok-kelompok dengan pendapat yang berbeda. Acemoglu et al. (2005) menyatakan bahwa institusi terbentuk dari pilihan kolektif masyarakat tersebut. Namun, tidak semua kelompok akan setuju dengan suatu rangkaian institusi karena rangkaian institusi yang berbeda akan menghasilkan alokasi sumber daya berbeda dan setiap kelompok pasti memilik "sefl-interest" masing-masing. Jika ada beberapa kelompok dengan preferensi institusi yang berbeda, institusi akan terbentuk dari kelompok yang memiliki kekuatan politik yang paling besar. Meskipun efisiensi lembaga atau institusi kelompok lain lebih dapat mendistribusikan sumber daya dengan baik, namun kekuatan politik yang lebih kuat dari suatu kelompok yang akan menentukan bagaimana rangkaian institusi di suatu negara. Hal ini mengakibatkan konflik kepentingan antar kelompok mengenai pilihan institusi yang menimbulkan sistem politik tidak stabil dan berdampak negatif bagi pertumbuhan ekonomi.

Selanjutnya, nilai t statistik political stability and absence of violence/ terrorism sebesar 2,268, lebih besar dari nilai t-tabel senilai 1,998. Dengan demikian, secara parsial variabel political stability and absence of violence/terrorism berpengaruh signifikan terhadap pertumbuhan ekonomi. Tanda positif pada koefisien mencerminkan arah pengaruh political stability and absence of violencel terrorism terhadap pertumbuhan ekonomi positif atau searah. Maknanya adalah setiap peningkatan 1 standar deviasi pada political stability and absence of violencel terrorism akan menyebabkan peningkatan pertumbuhan ekonomi sebesar 0,149 standar deviasi, demikian juga sebaliknya. Hasil tersebut juga sesuai dengan hasil penelitian Radulovic (2020) dan Bayar (2016).

Stabilitas politik merupakan gambaran keadaan pemerintah dari waktu ke waktu ketika terdapat distorsi dari berbagai peristiwa seperti pergantian kabinet atau kudeta. Ketika politik suatu negara tidak stabil berarti pergantian sistem pemerintahan terlalu sering. Hal itu juga mengindikasikan kebijakan ekonomi atau institusi ekonomi akan sering mengalami perubahan (Bayar, 2016). Institusi yang sering berubah sebagai akibat ketidakstabilan politik akan menimbulkan ketidakpastian dalam pengambilan keputusan ekonomi seperti investasi, produksi, dan penawaran tenaga kerja. Hal itu mengarah pada berkurangnya produktivitas kinerja ekonomi dan pada akhirnya menghambat pertumbuhan ekonomi. Jadi, stabilitas politik sangat penting bagi perkembangan kinerja perekonomian.

Kemudian, ditemukan bahwa secara parsial regulatory quality berpengaruh signifikan terhadap pertumbuhan ekonomi dibuktikan dengan nilai t statistik regulatory quality sebesar 9,264 lebih besar dari nilai t tabel sebesar 1,998. Koefisien yang bertanda positif menunjukkan arah pengaruh regulatory quality terhadap pertumbuhan ekonomi positif atau searah. Maksudnya, apabila regulatory quality meningkat sebesar 1 standar deviasi maka pertumbuhan ekonomi akan meningkat sebesar 0,781 standar deviasi, begitu juga sebaliknya. Penelitian ini sejalan dengan hasil penelitian Radulovic (2020) dan Ramadhan (2019).

Kualitas regulasi atau peraturan pemerintah yang baik akan mempercepat proses administrasi bisnis. Regulasi yang disusun pemerintah akan mempengaruh pertumbuhan ekonomi dengan mendorong sektor swasta melalui kemudahan dalam menjalankan bisnis. Sederhananya, seperangkat aturan dibutuhkan untuk mendorong pertumbuhan ekonomi (Ramadhan, 2019). Selain itu, regulasi juga disusun untuk mendukung kebijakan pemerintah dari sisi makro ekonomi untuk membantu menyesuaikan dengan perkembangan zaman

Di sisi lain, nilai t statistik control of corruption sebesar -0,786 yang lebih besar dari nilai -t tabel sebesar -1,998 membuktikan bahwa secara parsial control of corruption tidak berpengaruh signifikan 
terhadap pertumbuhan ekonomi. Hasil ini sejalan dengan penelitian Wibowo dan Prasetya (2013). Hal ini dapat terjadi karena upaya pencegahan kasus korupsi di negara berkembang masih lemah sehingga belum efektif dalam menekan kasus korupsi. Banyak permasalahan internal yang masih harus dihadapi sehubungan dengan reformasi di bidang politik dan sistem pemerintahan, tidak terkecuali reformasi birokrasi publik (Hariadi \& Luqman, 2013). Selain itu, pemberantasan korupsi di negara berkembang kurang didukung dengan kegigihan dan ketegasan para pemimpin dan masyarakatnya. Budaya korupsi di negara berkembang yang menganggap bahwa pemberian hadiah dan nepotisme adalah hal yang wajar menyebabkan program pemberantasan korupsi belum berdampak pada kondisi perekonomian (Lestari, 2017).

Sama halnya dengan pengeluaran pemerintah yang tidak berpengaruh signifikan terhadap pertumbuhan ekonomi secara parsial ditunjukkan dengan nilai t statistik sebesar 0,288 lebih kecil dari nilai $\mathrm{t}$ tabel sebesar 1,998. Menurut pendapat Othman, et al. (2018), pengaruh pengeluaran pemerintah tergantung produktif atau tidak penggunaannya. Hal ini menunjukkan bahwa pengeluaran pemerintah di Asia-9 tidak efektif dan efisien untuk investasi pelayanan publik. Dapat dikatakan bahwa pengalokasian belanja pemerintah tanpa mempertimbangkan prioritas program pembangunan, terutama untuk pelayanan publik yang dapat menghasilkan investasi. Pengeluaran pemerintah belum dialokasikan secara tepat sasaran untuk membangun stabilitas keuangan dan kebutuhan primer masyarakat seperti pendidikan, kesehatan, atau infrastruktur. Selain itu, belanja pemerintah tidak secara khusus ditujukan untuk meningkatkan pertumbuhan ekonomi makro. Hasil penelitian ini didukung oleh Anggraeni, Kalontong and Hukom (2020) yang meneliti tentang pengaruh pengeluaran pemerintah terhadap pertumbuhan ekonomi di Kalimantan Tengah. Hasil penelitian menunjukkan bahwa pengaruh pengeluaran pemerintah tidak berpengaruh signifikan terhadap pertumbuhan ekonomi karena alokasi belanja yang belum tepat sasaran.

Lebih lanjut, nilai t statistik FDI sebesar -7,303 lebih kecil dari nilai -t tabel sebesar -1,998. Hasil itu mengindikasikan foreign direct investment berpengaruh signifikan terhadap pertumbuhan ekonomi. Koefisien yang bertanda negatif membuktikan bahwa arah pengaruh FDI terhadap pertumbuhan ekonomi negatif atau berlawanan arah. Hal ini mengindikasikan jika arus masuk FDI meningkat sebesar 1 standar deviasi justru dapat mengakibatkan penurunan pertumbuhan ekonomi sebesar 0,585 standar deviasi, demikian pula sebaliknya. Hasil tersebut ssesuai dengan Dinh et al. (2019).

Proyek investasi dengan mendirikan usaha di negara lain yang dilakukan oleh perusahaan multinasional juga dimaksudkan untuk memperluas pasar sehingga sering kali mensyaratkan untuk menyertakan produk asli dari negara asalnya. Hal itu menyebabkan produk dalam negeri tidak memiliki pasar di negaranya sendiri karena skala perusahaan multinasional yang besar dan sudah memiliki pangsa pasar, berbanding terbalik dengan perusahaan domestik. Hal itu dapat memperburuk kondisi perekonomian dengan meniadakan pangsa pasar dan lapangan usaha bagi industri domestik.

Pengujian Pengaruh Tidak Langsung

Tujuan kedua penelitian ini adalah menguji pengaruh kualitas institusi dan pengeluaran pemerintah terhadap pertumbuhan ekonomi melalui FDI. Metode yang digunakan untuk memecahkan masalah ini adalah regresi data panel pendekatan common effect model, kemudian dilakukan analisis jalur dengan metode Uji Sobel untuk mengetahui signifikansi pengaruh tidak langsung. Hasil uji mediasi dapat dilihat pada tabel 2 di bawah ini.

Tabel 9. Hasil Uji Sobel Pengaruh Tidak Langsung

\begin{tabular}{llllll}
\hline Jalur & $\boldsymbol{a b}$ & $\boldsymbol{S a} \boldsymbol{b} *)$ & $\mathbf{t}$ statistik*) & t tabel & Ket. (2-tailed) \\
\hline $\mathrm{VA} \rightarrow$ FDI $\rightarrow$ GDP & 0,033 & 0,722 & 0,046 & 1,998 & Tidak signifikan \\
$\mathrm{PS} \rightarrow$ FDI $\rightarrow$ GDP & $-0,184$ & 0,887 & $-0,207$ & 1,998 & Tidak signifikan \\
$\mathrm{RQ} \rightarrow$ FDI $\rightarrow$ GDP & $-0,254$ & 1,902 & $-0,134$ & 1,998 & Tidak signifikan \\
$\mathrm{CC} \rightarrow$ FDI $\rightarrow$ GDP & 0,573 & 1,386 & 0,414 & 1,998 & Tidak signifikan \\
GS $\rightarrow$ FDI $\rightarrow$ GDP & $-0,112$ & 0,039 & $-2,900$ & 1,998 & Signifikan \\
\hline
\end{tabular}

Nilai t statistik pengaruh voice and accountability terhadap pertumbuhan ekonomi melalui FDI sebesar 0,033. Nilai tersebut lebih kecil dari nilai t tabel dengan $\alpha=5 \%(2$-tailed $)$ dan df $=71-7=64$ sebesar 1,998. Artinya, voice and accountability tidak berpengaruh signifikan terhadap pertumbuhan ekonomi melalui FDI.

Demikian pula untuk nilai t statistik pengaruh political stability and absence of violence/ terrorism terhadap pertumbuhan ekonomi melalui FDI sebesar -0,207 yang lebih besar dari pada nilai -t tabel sebesar 
-1,998. Dapat disimpulkan bahwa political stability and absence of violencelterrorism tidak berpengaruh signifikan terhadap pertumbuhan ekonomi melalui FDI.

Selanjutnya, didapatkan nilai $\mathrm{t}$ statistik untuk pengaruh regulatory quality terhadap pertumbuhan ekonomi melalui FDI sebesar -0,134. Nilai tersebut lebih besar dari nilai - tabel sebesar -1,998. Dari hasil tersebut dapat dikatakan bahwa regulatory quality tidak berpengaruh signifikan terhadap pertumbuhan ekonomi melalui FDI.

Begitu juga dengan hasil olah data yang menunjukkan bahwa variabel kualitas institusi control of corruption tidak berpengaruh signifikan terhadap pertumbuhan ekonomi melalui FDI. Hal ini dibuktikan dengan nilai t statistik sebesar 0,414 yang mana lebih kecil dari nilai t tabel sebesar 1,998.

Hasil penelitian ini sejalan dengan penelitian Asamoah, Mensah and Bondzie (2019) yang menemukan bahwa variabel-variabel kualitas institusi tidak berpengaruh signifikan terhadap pertumbuhan ekonomi melalui FDI. Hal itu dikarenakan FDI bukan merupakan faktor utama pertumbuhan ekonomi yang bersumber dari eksternal, meskipun pengaruhnya signifikan. Namun, ada hal lain yang lebih berpengaruh seperti sumbangan dari lembaga internasional dan bantuan pembangunan individual dari negara lain.

Selain itu, investasi yang masuk di negara berkembang lebih berfokus pada sumber daya yang ada di negara tujuan. Perusahaan multinasional mendirikan usaha di negara lain dalam rangka memperluas pasar sehingga mereka mencari lokasi dengan sumber daya yang dapat memudahkan proses produksinya. Sebagian besar sumber daya di negara berkembang yang belum dimanfaatkan secara optimal oleh negaranya menarik investor untuk mendirikan usahanya di negara berkembang.

Sementara itu, pada pengaruh pengeluaran pemerintah terhadap pertumbuhan ekonomi melalui FDI diperoleh nilai $t$ statistik sebesar -2,900. Nilai tersebut lebih kecil dari nilai -t tabel sebesar -1,998. Hasil tersebut menunjukkan bawah pengeluaran pemerinta $h$ berpengaruh signifikan terhadap pertumbuhan ekonomi melalui FDI. Tanda negatif pada koefisien memperlihatkan bahwa arah hubungan pengeluaran pemerintah terhadap pertumbuhan ekonomi melalui FDI negatif atau berlawanan arah. Jadi, setiap peningkatan pengeluaran pemerintah sebesar 1 standar deviasi maka pertumbuhan ekonomi menurun sebesar 0,112 standar deviasi melalui pengaruhnya terhadap FDI.

Berdasarkan pendapat Asamoah et al. (2019) investor lebih memperhatikan market size, sumber daya, dan bagaimana lingkungan negara tujuan investasi dilihat dari infrastruktur dalam bidang bisnisnya. Terlebih di negara berkembang yang sebagian besar sumber dayanya belum dimanfaatkan secara optimal, investor akan tertarik untuk berinvestasi dengan tetap memperhatikan fasilitas bisnisnya. Pengeluaran pemerintah yang dialokasikan untuk membangun infrastruktur di suatu negara dapat memudahkan mobilitas masyarakat sehingga meningkatkan produktivitas. Semakin baik infrastruktur di suatu negara dapat menarik aliran investasi masuk ke negara tersebut. Investor akan tertarik untuk berinvestasi di negara dengan fasilitas bisnis yang baik karena hal itu menandakan sarana dan prasarana yang memadai untuk menjamin kemudahan dalam melakukan proses berbisnis.

\section{KESIMPULAN}

Berdasarkan hasil penelitian yang telah dilakukan, dapat disimpulkan bahwa secara langsung variabel voice and accountability, political stability and absence of violencel terrorism, dan regulatory quality berpengaruh signifikan terhadap pertumbuhan ekonomi. Voice and accountability memilihi pengaruh negatif terhadap pertumbuhan ekonomi sehingga peningkatan partisipasi masyarakat dalam pemerintahan justru menurunkan tingkat pertumbuhan ekonomi. Sedangkan, political stability and absence of violence/ terrorism dan regulatory quality memiliki pengaruh positif. Artinya, ketika stabilitas politik dan regulasi yang diimplementasikan berkualitas dapat meningkatkan pertumbuhan ekonomi.

Demikian pula untuk variabel FDI yang berpengaruh signifikan terhadap pertumbuhan ekonomi secara langsung, tetapi arah pengaruhnya negatif. Jadi, semakin tinggi arus masuk FDI justru menurunkan tingkat pertumbuhan ekonomi. Sebaliknya, tidak ada pengaruh signifikan dari variabel control of corruption terhadap pertumbuhan ekonomi, Seperti halnya pengeluaran pemerintah yang tidak berpengaruh signifikan terhadap pertumbuhan ekonomi.

Di samping, itu, secara tidak langsung pengeluaran pemerintah berpengaruh signifikan terhadap pertumbuhan ekonomi melalui FDI. Hal ini berarti apabila porsi pengeluaran pemerintah terhadap PDB lebih tinggi maka akan menurunkan pertumbuhan ekonomi melalui pengaruhnya terhadap FDI. Berbeda hasilnya dengan semua variabel kualitas institusi yang tidak berpengaruh signifikan terhadap pertumbuhan ekonomi melalui FDI.

Dari hasil penelitian tersebut, peneliti merekomendasikan beberapa kebijakan. Pertama, berkaitan dengan kualitas institusi, pemerintah perlu melalukan reformasi regulasi dengan mengurangi regulasi yang tumpang tindih dan tidak jelas sehingga kuantitas regulasi menjadi lebih proporsional dengan muatannya. Kedua, dalam hal pengeluaran pemerintah, pembuat kebijakan diharapkan lebih mengefisienkan alokasi 
anggaran dengan meninjau kembali kebutuhan publik sehingga alokasi anggaran lebih tepat sasaran untuk kepentingan produktif. Ketiga, berhubungan dengan investasi dalam bentuk FDI, sebaiknya pembuat kebijakan lebih selektif salam menyaring FDI yang masuk ke negaranya arus masuk FDI tidak mengancam eksistensi industri lokal karena adanya persaingan dengan perusahaan multinasional. Sehubungan dengan pengeluaran pemerintah terhadap FDI dalam mempengaruhi pertumbuhan ekonomi, pengeluaran pemerintah hendaknya difokuskan pada penguatan industri internal, misalnya pemberdayaan UMKM untuk meningkatkan kemandirian ekonomi dandaya saing industri lokal dengan pasar internasional.

\section{DAFTAR PUSTAKA}

Abiad, A., Bluedorn, J., Guajardo, J. and Topalova, P. (2015). The rising resilience of emerging market and developing economies. World Development, 72, pp.1-26.

Acemoglu, D., Johnson, S. and Robinson, J.A. (2005). Institutions as a fundamental cause of long-run growth. In: P. Aghion and S.N. Durlauf, eds., Handbook of Economic Growth. Elsevier, pp.385472.

Alfaro, L., Kalemli-Ozcan, S. and Volosovych, V. (2005). Capital flows in a globalized world: The role of policies and institutions. In: S. Edwards, ed., Capital Controls and Capital Flows in Emerging Economies: Policies, Practices and Consequences. Cambridge, Ma: National Bureau of Economic Research.

Anggraeni, A., Kalontong, E. and Hukom, A. (2020). An analysis of employment and government expenditure on economic growth in Central Kalimantan Province. Proceedings of the Proceedings of the 5th International Conference on Science, Education and Technology, ISET 2019, 29th June 2019, Semarang, Central Java, Indonesia.

Anwar, C.J., Kuswantoro and Dewi, S.F. (2016). Faktor-faktor yang mempengaruhi foreign direct investment (FDI) di kawasan Asia Tenggara. Media Trend, 11(2), pp.175-194.

Asamoah, L.A., Mensah, E.K. and Bondzie, E.A. (2019). Trade openness, FDI and economic growth in sub-Saharan Africa: do institutions matter? Transnational Corporations Review, 11(1), pp.65-79.

Asghar, N., Qureshi, S. and Nadeem, M. (2015). Institutional quality and economic growth: Panel ARDL analysis for selected developing economies of Asia. South Asian Studies A Research Journal of South Asian Studies, 30(2), pp.381-404.

Badan Pusat Statistik (2020). Laporan perekonomian Indonesia 2020. Jakarta: Badan Pusat Statistik Indonesia.

Case, K.E., Fair, R.C. and Oster, S.M. (2012). Principles of Macroeconomics. 10th ed. USA: Prencite Hall, Pearson.

Daniele, V. and Marani, U. (2006). Do institutions matter for FDI? A comparative analysis for the MENA countries. SSRN Electronic Journal, pp.1-28.

Farasianita, I.S. (2019). Analisis pengaruh kebijakan defisit anggaran terhadap pendapatan nasional dan investasi di Indonesia tahun 2011Q1-2018Q4. Skripsi.

Febriana, A. and Muqorobbin, M. (2014). Investasi asing langsung di Indonesia dan faktor-faktor yang mempengaruhinya. Jurnal Ekonomi dan Studi Pembangunan, 15(2), pp.109-117.

Felipe, J., Abdon, A. and Kumar, U. (2012). Tracking the middle-income trap: What is it, who is in it, and why? SSRN Electronic Journal, (715).

Hariadi, T. and Luqman, H. (2013). Perbandingan penanganan tindak pidana korupsi di nerara Singapura dan Indonesia. Recidive, 2(3), pp.265-279.

Hidayat, A. (2008). Integrasi ekonomi Asia: Solusi Asia menghadapi krisis global 2008. The Winners, 9(2), pp.180-190.

Huang, C.-J. and Ho, Y.-H. (2016). Governance and economic growth in Asia. The North American Journal of Economics and Finance, 39, pp.260-272.

International Monetary Fund (2020). World economic outlook: A long and difficult ascent. Washington DC: International Monetary Fund.

Jhingan, M.L. (2011). The economics of development and planning. 40th ed. Delhi: Vrinda Publication.

Kaufmann, D., Kraay, A. and Mastruzzi, M. (2011). The worldwide governance indicators: Methodology and analytical issues. Hague Journal on the Rule of Law, 3(02), pp.220-246.

Lestari, Y.S. (2017). Korupsi: Suatu kajian analisis di negara maju dan berkembang. Community, 3(2), pp.180-195.

Mankiw, N.G. (2010). Macroeconomics. 7th ed. New York: Worth Publishers. 
Mankiw, N.G. (2018). Principles of economics. 8th ed. Boston: Cengage Learning.

Masron, T.A. and Abdullah, H. (2010). Institutional quality as a determinant for FDI inflows: Evidence from ASEAN. World Journal of Management, 2(3), pp.115-128.

North, D.C. (1990). Institutions, institutional change and economic performance. New York: Cambridge University Press.

Oktaviani, S., Aimon, H. and Putri, D.Z. (2019). Analisis variabel moneter Amerika Serikat terhadap pertumbuhan ekonomi negara emerging market. Jurnal Kajian Ekonomi dan Pembangunan, 1(2), pp.223-240.

Othman, N., Yusop, Z., Andaman, G. and Mansor, M. (2018). Impact of government spending on FDI inflows: The case of ASEAN-5, China and India. International Journal of Business and Society, 19(2), pp.401-414.

Priyajati, H.A. and Haryanto, T. (2020). Hubungan logistik terhadap pertumbuhan ekonomi: Studi kasus 9 negara emerging. Media Trend, 15(1), pp.133-146.

Radulovic, M. (2020). The impact of institutional quality on economic growth: A comparative analysis of the EU and non-EU countries of Southeast Europe. Economic Annals, 65(225), pp.163-181.

Ramadhan, M. (2019). Assessing of the impact of good governance and institutions on economic growth in Indonesia. International Journal of Scientific \& Technology Research, 8(11), pp.2594-2598.

Todaro, M.P. and Smith, S.C. (2012). Economic development. 11th ed. Boston: Addison-Wesley.

Wibowo, E. and Prasetya, F. (2013). Analisis pengaruh kualitas pemerintahan terhadap pertumbuhan ekonomi di ASEAN. Jurnal Ilmiah Mahasiswa FEB, 1(12).

Yuan, Y., Chen, Y. and Wang, L. (2010). Size of government and FDI: an empirical analysis based on the panel data of 81 countries. Journal of Technology Management in China, 5(2), pp.176-184.

Zahran, V.Z.Z. (2020). Pengaruh foreign direct investment dan ekspor terhadap pertumbuhan ekonomi Indonesia. Jurnal Ilmiah Mahasiswa FEB, 8(1), pp. 